\title{
As várias faces de uma história
}

Prolessora coordenedora: Mara de Fatme Moreti Alunos boslstas: Maria Paula Cavaho Bonllha

\section{NelMassa}

O presente texto tem como objetivo relatar a experiência da oficina As várias faces de uma história, desenvolvida pelos bolsistas de Artes Cênicas no âmbito do NUPEART, projeto que alia ensino, pesquisa e extensão na Universidade de Estado de Santa Catarina.

Tendo concluído o projeto experimental no segundo semestre de 2000, a coordenação de Artes Cênicas reformulou a metodologia, contéudo e abordagem da oficina, visando a uma maior interação e envolvimento dos bolsistas, alunos e professores que participam das atividades do núcleo.

Somado ao ensino de arte-educação por meio do Teatro de Formas Animadas (Teatro de Sombras, de Bonecos e de Máscaras) de forma preponderante, o núcleo de Artes Cênicas apostou no desenvolvimento de elementos da narratividade, na construção da dramaturgia e na contação de histórias como fio condutor desta oficina.

A experiência do 'fazer teatral' perpassado pela atividade de recepção, criação e reelaboração de histórias, tanto em nível individual como em grupo, tem se mostrado eficaz no exercício da criatividade, no aumento da capacidade de concentração e da consciência do trabalho de grupo para a atividade teatral e para a vida cotidiana das crianças.

\section{A oficina}

A organização das aulas prevê dois momentos distintos. $\mathrm{Na}$ primeira parte, o aquecimento corporal e a 
concentração são obtidos por meio de jogos de integração em grupo. Num segundo momento, o desenvolvimento do Teatro de Formas Animadas concretiza-se em vivências direcionadas à construção de bonecos a partir da manipulação de ferramentas e materiais como papel, sucatas, espumas, arames, colas, entre outros.

Comprometido com a construção cênica a partir de uma história por ele elaborada ou sugerida pelo professor, o aluno toma consciência da importância dos elementos presentes na cerimônia espetacular e da convenção teatral. Entre outros conteúdos, o aluno visualiza a sua importância como agente da ação dramática e o lugar do público no fenômeno da comunicação (emissão/recepção). Percebe também a necessidade de criação e colocação da voz, da elaboração dos movimentos que dão vida aos objetos, bonecos e máscaras e ainda, do aprendizado da disciplina como item fundamental na composição das ações dos personagens.

A inclusão do desenvolvimento da dramaturgia e da narratividade permitiu ainda avançar na metodologia de ensino do Teatro de Formas Animadas. A partir da construção dos bonecos e do entendimento da fábula como arcabouço narrativo, novas possibilidades de elaboração dos personagens, ações e conflitos dramáticos modificaram o rumo da encenação. Isto porque, sustentado pela estrutura da fábula e pelo incentivo dos professores, o aluno pode exercer livremente sua imaginação e, desta forma, reorientar as atividades.

Em outras palavras, a história passa a ser a semente de um processo de permanente reelaboração que pode alçar vôos inesperados no momento da confecção de bonecos e na posterior encenação. A construção da dramaturgia e encenação finais poderão estar quase que na sua totalidade guiadas pelo 
processo criativo dos alunos, que ousam romper com as estruturas fornecidas pelas histórias para proporem, então, suas próprias formas narrativas, soluções aos conflitos dos personagens, ou ainda, a criação de novos personagens.
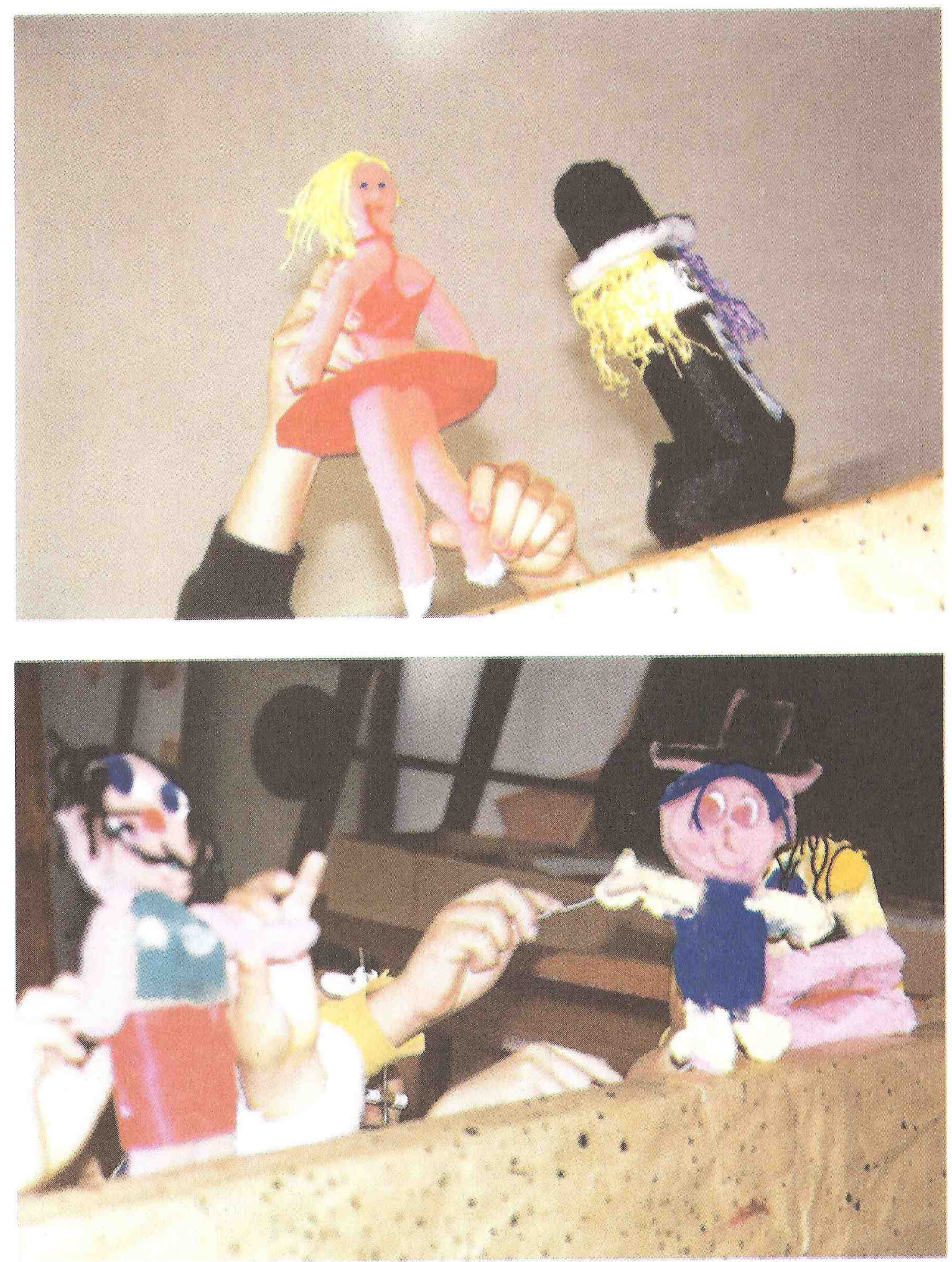